\title{
Maize in Umbria (central Italy). Market, prices and farms between the eighteenth and nineteenth centuries
}

\author{
Manuel Vaquero Piñeiro \\ University of Perugia, Department of Political Sciences
}

\section{Introduction}

Among all the plants shipped in cargo holds from the New World (Plantes et cultures 1992), there is no doubt that maize exerted a special influence on both the old continent's food habits and the crucial changes which occurred in its agricultural landscape during the modern age (Sereni 1997). In 1511, Pietro Martire d'Anghiera, from Lombardy, wrote about it for the first time in his book Decade de Orbe Novo and, in 1532, maize was already mentioned in Italian herbals (Doria 2002, 570-571; Gentilcore 2017). As was usual with rare and exotic plants which originated from distant lands and bore suggestive names evocative of the East (Heine 2017), maize initially found its placement in the gardens, where it drew attention and curiosity (Ambrosoli 1992). However, its transition from gardens to cultivated fields took place quickly (Rebourg 2002), since the use of this plant from the Indies immediately took hold in livestock feeding (Cazzola 2014). Moreover, maize waste produced useful fuel and mulch. At the end of the sixteenth century, Agostino Gallo from Brescia devoted several pages of his essay Le giornate di agricoltura to the subject of maize, thus demonstrating that this cultivation was becoming familiar as well as widespread in many areas of the Italian countryside.

Imported in Italy from Spain towards the end of the fifteenth century, maize was already being cultivated in the Venetian mainland during the first half of the sixteenth century (Finzi 2009). During the following dec- 
ades, the maize-planted area in the Italian Peninsula grew so much that it included Tuscany and Terra di Lavoro, before reaching its final state in the early seventeenth century. In 1620, maize made its appearance in the irrigated lands of Bergamasco, therefore taking hold in the Ferrara area. Around the 1660 s, maize spread in Lombardy where, in 1649, the Municipality of Milan had ordered the city to be supplied with this new cereal (Coppola 1979; Cova 1992). Maize crops continued to propagate during the second half of the seventeenth century by reaching Treviso, Vicenza and Padua. Over this same period, it made its appearance, though episodic, in Umbria and Marche. In the eighteenth century, it spread further to Piedmont and to the Bologna area. The ble de Turquie even arrived in the southern areas (Cuocco 2008) where, due to the climate, wheat was the most common crop. However, during the modern age, a dualism in cereal cultivation took shape which immediately affected the landscape: on the one hand, there was the south with its wheat fields, which were an emblem of dry agriculture, while, on the other hand, there were the northern valleys, where the coexistence of maize and wheat produced a much more variegated agricultural space, far richer in feeding options, both for people and livestock. At the same time, the spreading of maize crops improved peasants' as well as merchants' commercial strategies which, starting from the mid-seventeenth century, had a greater choice of products to be placed on the market, according to trends in harvests and prices (Levi 1991).

Public authorities and large landowners, merchants and small street vendors started to impose the cultivation of maize on the peasants, though facing much resistance due to the fact that, in several lands, its planting resulted in a reduction in other cereal crops, such as rye and millet, which had been for centuries essential parts of diets and cultivation practices. Anyway, in the light of the immediate advantages that it offered, maize took hold as a minor grain, soon becoming the typical food of both rural and urban lower classes (Mocarelli 2015). Although representing a makeshift food, compared with the finer wheat, maize provided peasants and the poor urban class with a useful solution to satisfy hunger and remove the threat of it. Moreover, other reasons favoured the peasants' overcoming their initial resistance and contribute to explaining the spreading of maize in the European, and consequently Italian, countryside. First of all, as mentioned above, maize represented a fairly reliable and steady food not only for people, but also for the livestock, which was soon fed with it. Even though specific research concerning the connections between the in- 
crease in maize crops and the increase in livestock, especially bovine, is still lacking, the latter increase was a rather manifest phenomenon during the eighteenth century. Research focused on the role played by maize in peasant self-consumption (Visceglia 1991) should be deepened too, so as to include, for instance, the use of waste in the production of mattresses and fuel, which became more common in popular houses. These themes should in fact find their place within the articulate debate devoted to the gradual improvements in the rural classes' health and quality of life, which represented a fundamental prerequisite of the demographic acceleration of the eighteenth century (Livi Bacci 1987).

On the basis of a rich bibliography, which allows us to compose a solid historiographic framework, this work aims at moving from a general approach towards a more regional one, focused on companies' behaviour. The case study of Umbria, a region located in the centre of the Italian Peninsula, offers the possibility to verify the general theories. The chronological frame selected for this investigation ranges from the early eighteenth century, when maize - called mais, granoturco or formentone in Italian - began to regularly appear in the region (Franconie 1997; Messedaglia 1927), to 1861, the year the Italian Kingdom was founded. This research, embracing almost a century and a half, aims at better defining the time frame of the spreading of maize in Umbria; from its first appearance to its systematic presence among the cereals traded in the regional markets and grown on local farms. Available data from companies' and markets' accounting books (from Assisi, Gubbio, Perugia and Orvieto) provide us with information not only relevant for understanding the regional features, but also for elaborating long-term interpretations.

Other than determining the phenomenon's time frame, the goal of this study is to elaborate tables regarding trends in maize prices by composing a single regional picture through the aggregation of data derived from different sources. A comparison of maize prices from different markets and different companies allows us to identify potential strong differences among them or rather a general convergence tendency. As is well known, research aimed at identifying divergences or convergences in the Ancien Régime markets (Epstein 2002) usually refers to wheat prices, for obvious reasons. Without overlooking the relevance of wheat in the preindustrial society, this case study refers to maize prices in order to achieve two main goals: firstly, to ascertain whether trends in maize prices are diverging or converging depending on the examined commercial areas and, secondly, to 
draw a comparison between the evolution of maize and wheat prices in order to eventually verify the possible emergence in the early modern period of a single market of cereals made up of finer grains, such as wheat, and of grains reputed to be of lower quality, such as maize (Vivanti 1967).

The third goal of this research is that of assessing the information derived from the accounting records of farms in order to specifically appraise the relevance of maize among their crops. Moreover, large companies' accounting records give more than a hint regarding food prices (Poni 1978) which, in some cases, allow us to compose fairly consistent and prolonged series. These series are an interesting key to the understanding of the big owners' economic strategies, while at the same they allow us to evaluate trends in maize prices from two points of view which are comparable: "market prices" from records in the accounting books of city markets, and "company prices" from records in the companies' accounting books.

\section{Maize in Umbria's markets and farms}

Sharecropping affected the evolution of agricultural activities in Umbria until the second half of the twentieth century (Nenci 1989), while maize began to spread throughout this Italian region in the early eighteenth century. At the beginning of the eighteenth century, maize had indeed made its appearance, not only on farms but also in urban markets, thus demonstrating that this new plant, which would soon transform the agricultural landscape, was not restrained to the agricultural sphere. On the contrary, urban markets played a fundamental role in the success of this plant from the Americas. Records from the market of Gubbio provide evidence of the price of a mina of maize since 1727 (Graph 1). Chronological findings from other cities place the appearance of maize around the mid-eighteenth century: in Assisi in 1741 (Graph 2) and in Perugia in 1766.

Evidence concerning the second half of the eighteenth century reveals that the maize crops had already taken hold in the lands around Perugia; a situation which would improve further under French domination. Nonetheless, maize became a steady presence in the Orvieto market only after 1813 (Graph 4). This timeline is the same as in the nearby cities of Tuscany (Mocarelli and Vaquero Piñeiro 2018) where maize trade also took hold around the end of the eighteenth century: since 1780 in Sarteano, 1793 in Castiglione Fiorentino, and 1802 in Cortona. 


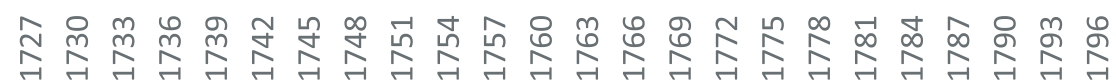

Graph I. Maize price in Gubbio, 1727-1796 (in Baiocchi per mina)

Source: Mocarelli and Vaquero Piñeiro 2018.

18

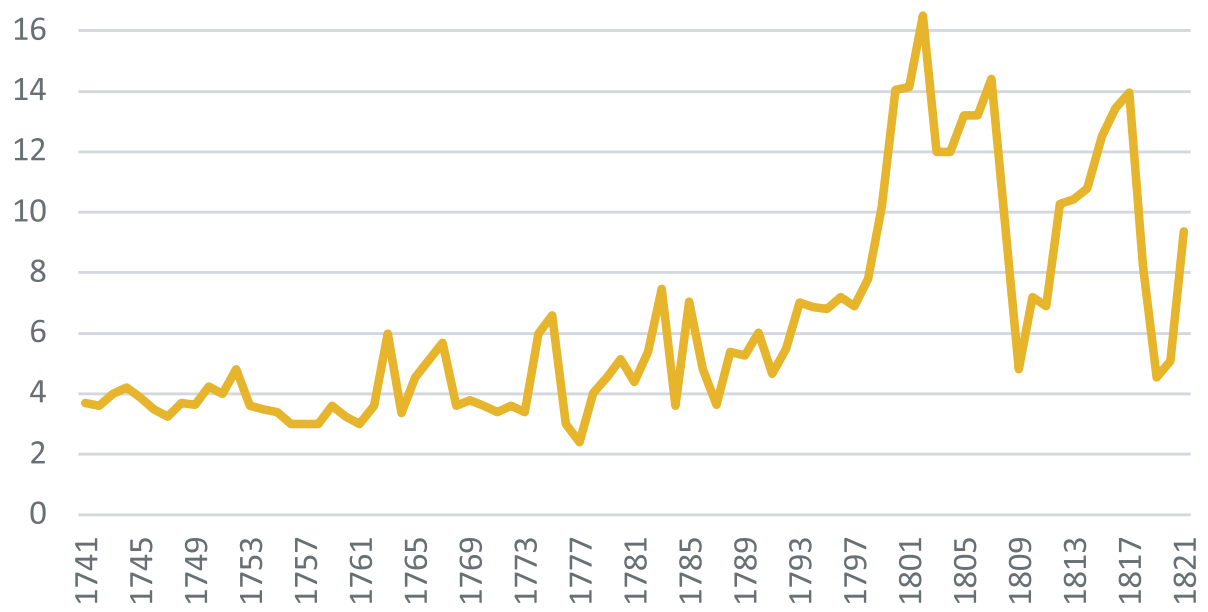

Graph 2. Maize price in Assisi, 1741-182I (in Scudi per rubbio)

Source: Mocarelli and Vaquero Piñeiro 2018 


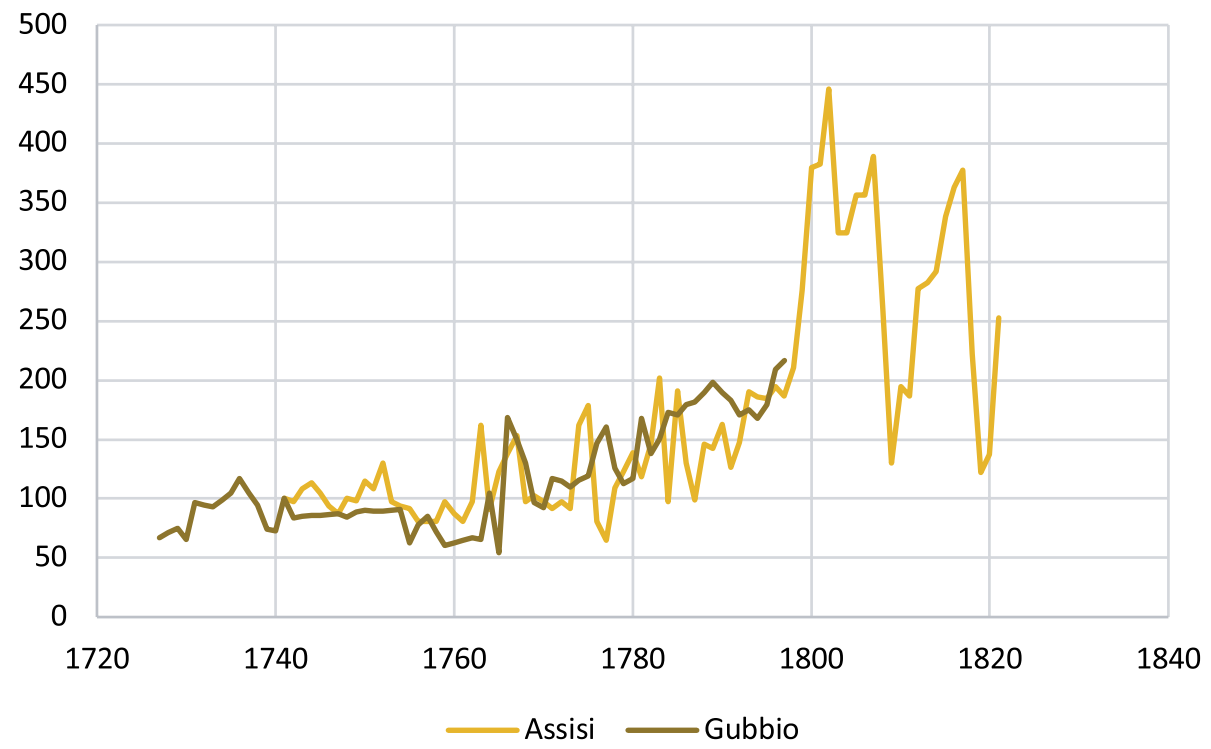

Graph 3. Maize price index in the markets of Gubbio and Assisi, 1727-1821 Source: Author's data processing of Graphs I and 2.

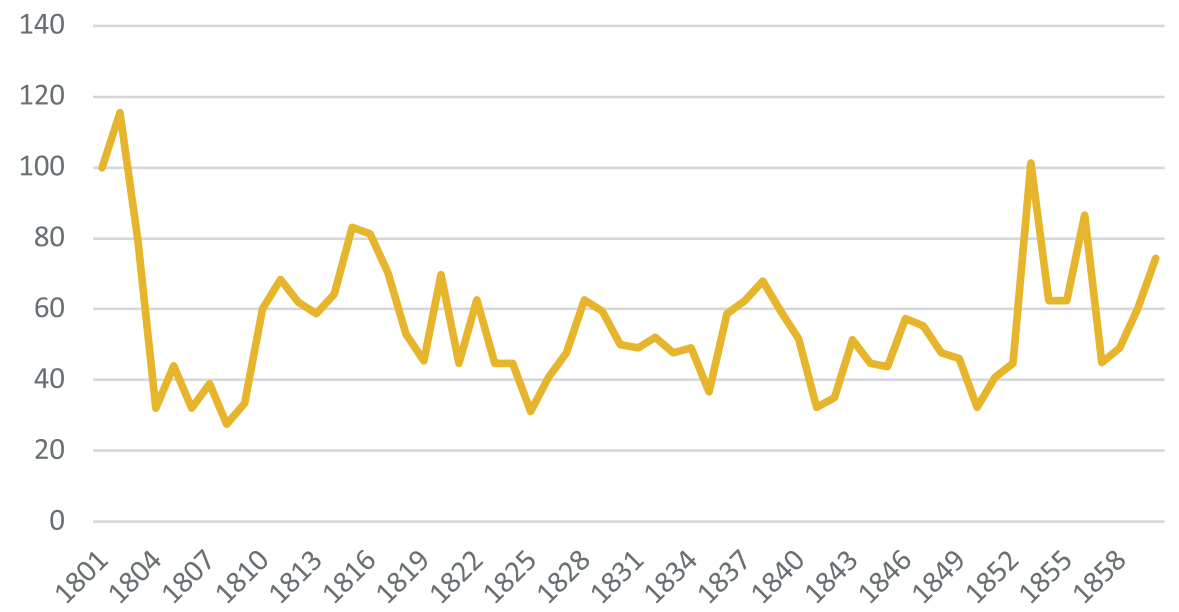

Graph 4. Price of a staio of wheat, Sicily's wheat and Orvieto's maize, I80I-1860.

Average index $(\mathrm{I} 8 \mathrm{IO}=\mathrm{I00})$

Source: Mocarelli and Vaquero Piñeiro 2018.

Once established that maize entered Umbria's market during the eighteenth century and took hold there in the transition to the nineteenth 
century, it is important to verify its presence in individual city markets and to determine in which period it started to actually be cultivated in local farms. Theoretically, these two phenomena may not concur since city market supplies of seeds and cereals hinged upon several factors other than the companies' production, such as imports from other regions and the dissemination capability of seed and cereal traders. By examining the phases of maize expansion in Umbria, a complex scenario emerges. On the basis of available findings regarding this region, it seems therefore possible to introduce some variations to the theory according to which maize firstly appeared on farms and, later, in the markets (Levi 1991, 156). In our case study, in fact, the two processes have proved to be concurrent. Before addressing the data derived from the farms' accounts, it is necessary to focus on two of Umbria's neighbouring regions: Marche and Tuscany. In the Marche region, first records about the presence of maize among the local crops refer to the last years of the seventeenth century when initial small quantities were attested, which demonstrate that maize was still a novelty (Moroni 2016). In the case of Tuscan farms too, maize made its appearance among other crops during the last years of the seventeenth century and then took hold in the early eighteenth century (Mineccia 1983). The available information suggests that maize arrived on Umbrian farms at the very beginning of the eighteenth century, following a north-to-south route through the Tiber Valley. Awaiting new findings which will prove this hypothesis, we can only affirm at the moment that maize firstly appears in the accounting records of the Bufalini family from San Giusto in 1707 (AB, 359, 110). This is a relevant piece of information because, due to the closeness of Bufalini's lands to Tuscany and their commercial relations with the Emilia region, it allows to hypothesize that this geographical area was one of the main paths of maize to Umbria. Not by chance, data concerning the central part of the region are chronologically successive. In the Pio Collegio of the University of Perugia, the first reference to maize dates back to 1766 (AUP, $L E U, 1766-1784$ ); on the properties of the noble family of Bourbon di Sorbello the first reference to maize appears in 1806 and, in this case, it is called "Sicily wheat" (ASP, ABS, I, 59). Another evidence of the nineteenth century consolidation of maize presence on large Umbrian farms comes from the Degli Oddi family's lands where, in 1802, the distribution of small quantities of maize seeds was noted for the first time among small farmers. After these first steps, maize was able to spread quickly. Likewise, in the case of the lands of the Benedictine monastery of San Pietro in Perugia, 
maize regularly appears on the list of crops only after 1816 (AMSPP, LE, 49). At present, it is therefore evident that in the early eighteenth century, maize had arrived in Umbria almost concurrently in both city markets and farms and afterwards continued to strengthen its presence until the first half of the nineteenth century. It still remains to be clarified whether the maize traded on Umbrian markets was actually cultivated on local farms or was rather imported from other regions. Compared with the well-researched subject of the wheat commercial circuits, however, maize marketing is much less known, as if it was exclusively meant for family consumption (Galli 2016). Actually, alongside the self-consumption among peasant families, the steady presence of maize in city markets induces to envision the emergence of a diversified cereal trade during the early modern period, no longer dominated by wheat but by two cereals: wheat and maize. Moreover, with the entry of maize into the markets a greater range of trade options emerged with regard to demand and offer.

Although fresh research is needed in order to deepen this analysis, especially regarding the main actors of the maize trade, a plausible starting point is the knowledge that maize was systematically cultivated in Umbria at the beginning of the nineteenth century. From that moment on, farming activities were based on a wheat/maize alternation which endured until the mid-twentieth century (Desplanques 1969; Vaquero Piñeiro, Giommi 2017). Moreover, though a direct connection between the spreading of maize and population growth still needs to be proved, the strong population growth registered in Umbria, lasting almost a century, should be seen as more than a mere chance. Between 1802 and 1911, an $88 \%$ population increase was recorded (Bonelli 1967, 29). In order to understand such a positive trend, it is necessary to consider both the physical and the psychological effects that the greater availability of food produced on the lower classes. Despite its poor nutritional properties, in fact, maize offered a precious alternative to the constant danger of hunger and famine (Alfani 2010; Alfani and Ó Gráda 2017). Obviously, the downside of the unbalanced maize consumption was pellagra, though the link between this disease and maize did not become commonly known until the nineteenth or even the early twentieth century (De Bernardi 1984; Finzi 1982).

\section{Maize prices in Umbria (1700-1861)}

There is no need to remind you that trends in wheat prices have brought about the elaboration of detailed series of prices and several theories about 
economic and demographic cycles in the Ancien Régime European society (Romano 1967). At any rate, while researching the trends in prices and wages in Milan during the eighteenth century, Aldo de Maddalena brought scholars' attention to the need to include maize among the commodities which determined offer and demand on the Milan market (De Maddalena 1974, 108).

It must be emphasized that the results of the analysis based on data concerning Umbria are still partial and provisional. However, despite difficulties in interpreting different currencies and units of measurement, depending on different markets and geographical areas, the collected findings highlight perfectly synchronized prices in all the markets considered. This allows us to recognize some general phases relevant for all the areas examined. The first long phase of relatively steady market prices can be identified from the first half to the 8 os of the eighteenth century, which was interrupted between 1765 and 1767 and between 1774 and 1775 by two intervals of growing prices. In Assisi, from 1741 to 1764 the average price of a staio ${ }^{2}$ of maize was around $3.69 \mathrm{scudi}^{3}$, which later grew to $5 \mathrm{scudi}$ between 1765 and 1767; once the subsistence crisis of the 1760 os had been overcome (Gori $1989,573)$, a staio fell to 3.5 scudi, with the exception of the 1774-1775 interval when the maize price started to rise again up to 6-6.6 scudi. Between 1778 and 1798, average prices in the Assisi market (Graph 2) began to move upwards, reaching 5.68 scudi. This represented a 54\% increase compared with the mid-century prices. These data can be compared with those from the Gubbio market, where maize prices were expressed in baiocchi for a mina (Graph 1). In this second case too, we can observe a phase of price stability lasting until 1765, followed by a phase of increasing prices between 1766 and 1768, when the price of a mina of maize reached 143 baiocchi (between 1766 and 1768 the average price was 77.9 baiocchi for a mina) before dropping again to 103.20 baiocchi in 1775. Both in Gubbio and in Assisi, from the mid70 s to the end of the eighteenth century, maize prices experienced a significant growth: between 1776 and 1797 a mina reached the average price of 161.5 baiocchi per year, that is a $107 \%$ increase since the middle of the century.

The examined dynamics show that, during the eighteenth century and before the 1798 breakdown triggered by the arrival of French armies, it is possible to identify four phases in the trend of cereal prices in the Umbrian

3 The scudo was the currency of the Papal States until 1866. It was divided into 100 baiocchi. 
city markets: the first phase (1730-1764) marked by steady and low prices; the second phase marked by a price growth between 1765 and 1768; the third phase marked by a new stability lasting until the second half of the 1770 s and, lastly, the fourth phase of a new increase between 1776 and 1778, which stopped with the end of the century due to the invasion of Jacobin armies. Generally speaking, the increases in agricultural prices that occurred during the second half of the eighteenth century favoured, for several reasons, the expansion of production (Caracciolo 1973, 547-548). By examining the cereal price fluctuations in the urban markets, it is possible to better understand the rationale for maize propagation in a region with Umbria's features, where soil and climate were not particularly suitable for this crop. In fact, it is possible to assume that the increasing prices induced to replace the traditional fallow fields with more useful crops, thus contributing to the shaping of a binary agricultural structure (wheat/maize) which would last until the great changes of the second half of the twentieth century.

Between the end of the eighteenth and the beginning of the nineteenth centuries, during the French military invasion, the available data regarding Umbrian markets show a significant increase in the price of maize. In Assisi, the average price of a staio between 1798 and 1817 was about 11.35 scudi, though it reached the value of 14 scudi in 1800-1801 and in 1807, and even of 16 scudi in 1802 (Graph 2). By comparing this trend with those of a few decades earlier, an increase of well above $127 \%$ can be registered. A mild slowdown took place only between 1808 and 1811, when the staio price fell to 6.80 scudi. However, even after 1818, notwithstanding a significant fall in prices, the average maize value remained double compared with the mid-eighteenth-century trend. In the nearby Tuscan city of Castiglione Fiorentino similar trends can be observed. Between 1794 and 1801, the price of a staio of maize was steadily around $6.6 \mathrm{libre}^{4}$, with a $64 \%$ increase from the 4.05 libre of the previous years. Similarities between these trends and those in Assisi allow us to speak about a contraction in 1801 followed by a substantial increase between 1810 and 1816, when a staio of maize reached the value of 6 libre. In 1817 a long phase of low prices began, thus determining a new trend which lasted until the birth of the Kingdom of Italy in 1861. The only exception is the 1853-1856 interval, when the price of a staio of maize reverted to 9-11 libre.

During the nineteenth century, similar trends can be observed in the Cortona, Orvieto and Sarteano markets. The phase of increasing prices 


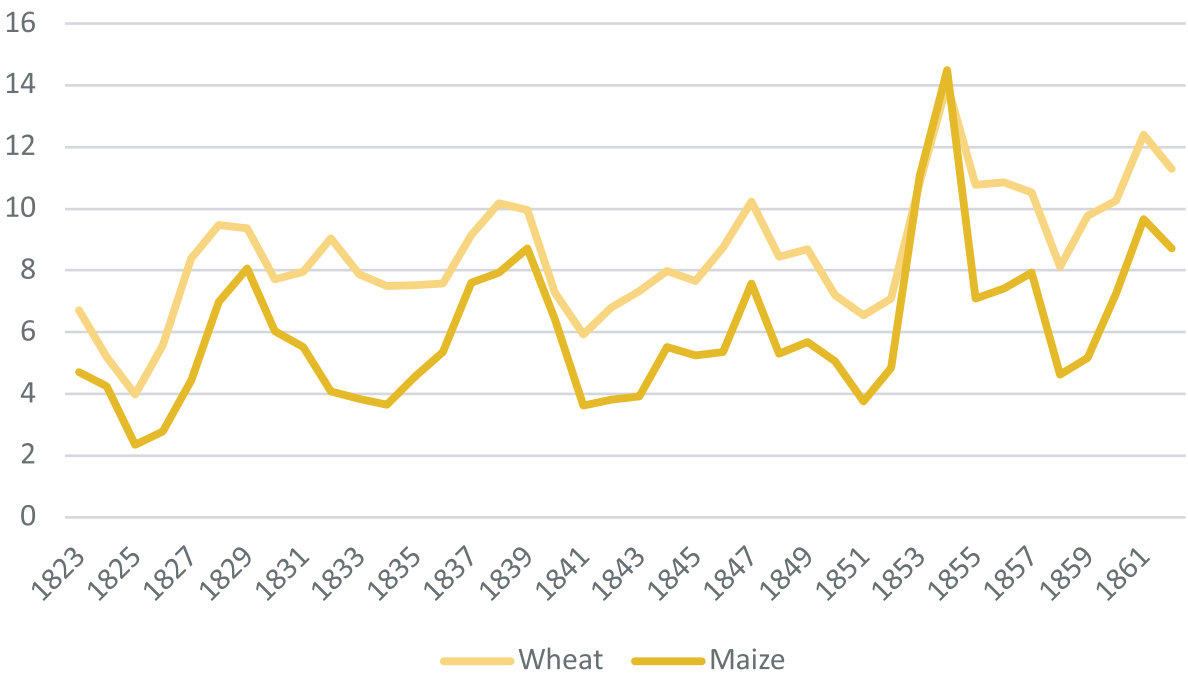

Graph 5. Wheat and maize market prices in Perugia, 1823-1862 (in Scudi per rubbio) Source: ASPG, Antonini, series 7, no. 5 .

which marked the period between the end of the eighteenth century and 1817, with a temporary contraction between 1804 and 1810, was followed by decades of stable and low prices, with the exception of short periods of price recovery (1828-29, 1838-39, 1853-54). It is important, at this stage of the research, to point out the strong chronological synchrony exhibited by the different markets examined, which were located on both sides of the border between the Grand Duchy of Tuscany and the State of the Church (Biagioli 2000, 523). In fact, this means that, though belonging to two different political institutions, these markets shared a common price trend due to the sharing of a common commercial network, thus contributing to the shaping of a single and integrated economic space (Persson 1999).

Another important issue to address concerns the interaction among prices of different cereals. Our first study case in Umbria is the city of Orvieto (Graph 3), where the price trend of different cereals on the city market (wheat, Sicily wheat and maize) can be traced from the beginning of the nineteenth century until the birth of the Kingdom of Italy in 1861. Looking at this trend, it is possible to notice that increases and contractions in the prices of different cereals follow a similar pattern during the first half of the nineteenth century, thus confirming the emergence of a single market despite the adoption of different cereal policies on the part of the pre-unitary Italian States (Pescosolido 2007). A synchronized pattern also marked 
wheat and maize prices in the Perugia cereal market (Graph 5). Even in the main Umbrian city it is indeed possible to identify, during the first half of the nineteenth century, a prolonged phase of partial stability which started in the 1820 s and ended in the early 1850 , when sudden surges in prices took place between 1852 and 1853 and between 1856 and 1857. During its last ruling years, the Church reimposed low prices especially for maize, while wheat prices continued to be high, on the backdrop of an overall fluctuating trend which endured from 1857 to 1861.

In the market of Sarteano, a small town located between the State of the Church and Tuscany, the price trends of the two main cereals appear perfectly synchronized from 1780 to 1835 , with parallel surges and downward trends. Overall, five phases can be identified in the markets of the cities examined. The first phase of moderate prices lasting until 1792 was followed by the second phase of a price increase between 1793 and 1803 (an $85 \%$ increase for wheat and a $152 \%$ increase for maize), the third phase of a new downward trend until 1810, and by another remarkable increase between 1811 and 1817 (a 62\% increase for wheat and 90\% for maize). At the end of the French invasion, prices decreased again until they reached the same levels as in the 1780 os. Alongside this synchronized trend of wheat and maize prices, it is possible to observe that in the most critical periods (17931803 and 1811-1817) there was a clear reduction in the value difference between the two cereals, due to a more sensitive increase in maize prices. In fact, in the three phases of market calm (1780-92, 1804-10 and 1818-35), the gap between wheat and maize prices reached $43-47 \%$, while it dropped to 28-37\% during the periods of greater instability (1793-1803 and 1811-1817). As demonstrated by research carried out on both French (Labrousse 1932) and Italian study cases (Malanima 1976; Gori 1989, 573), this was due to the fact that, in a time of crisis, reduced food supplies tend to favour the most expensive cereals by neglecting the humbler ones. In consequence, in these periods many peasants and small owners who would have been able to satisfy their family food needs with their own production under normal conditions, were forced to resort to the market, thus triggering a price increase due to the growing gap between an increased demand and a reduced offer. This twofold mechanism is clearly manifest in the case of maize which, in times of famine, tended to disappear from urban markets and become a rare and expensive commodity for the low classes, while coming back in periods of a price decrease. 


\section{Maize cultivation on large agricultural estates}

Having retraced the timeline of the spreading of maize in Umbria and examined its price trends, with special attention paid to the emergence of a single commercial space marked by converging prices, we can now focus on sources concerning farms' activities in order to investigate, though in the form of a primary survey, the role played by large landowners in determining the maize offer. To this end, it is possible to consider the data regarding some Umbrian farms' activities throughout the nineteenth century. Between 1816 and 1850 the Casalina company (Table 1) - the core of the land property of the San Pietro Benedictine monastery in Perugia - produced about 2,960 staia of maize and wheat, with a clear predominance of wheat which amounted to $63 \%$ of the company's entire cereal harvest. Obviously, over an almost 30-year period there were significant fluctuations, during which maize moved from a minimum percentage of $14 \%$ in 1817 to a maximum of $63 \%$ in 1844 . Between these two extremes, it averagely ranged from 37 to $44 \%$ of the cereal crops.

Table I. Wheat and maize production in the Casalina company of the Perugia San Pietro monastery, I816-186I (Staia).

\begin{tabular}{|c|c|c|c|c|}
\hline Years & Wheat & Maize & Total & $\begin{array}{c}\% \text { of maize } \\
\text { in total amount }\end{array}$ \\
\hline 1816 & 2,113 & 808 & 2,921 & 28 \\
\hline 1817 & 3,507 & 572 & 4,079 & 14 \\
\hline 1818 & 2,515 & 1,019 & 3,534 & 29 \\
\hline 1841 & 1,916 & 870 & 2,786 & 31 \\
\hline 1842 & 2,135 & 1,593 & 3,728 & 43 \\
\hline 1843 & 1,312 & 1,052 & 2,364 & 44 \\
\hline 1844 & 1,312 & 1,052 & 1,656 & 63 \\
\hline 1845 & 892 & 737 & 1,629 & 45 \\
\hline 1846 & 854 & 475 & 1,329 & 36 \\
\hline 1847 & 1,894 & 1,186 & 3,080 & 38 \\
\hline 1848 & 1,392 & 823 & 2,215 & 37 \\
\hline 1849 & 2,484 & 1,121 & 3,605 & 31 \\
\hline 1850 & 2,850 & 1,650 & 4,505 & 37 \\
\hline 1850 & 2,542 & 1,477 & 4,019 & 37 \\
\hline Median & 1,966 & 994 & 2,960 & 37 \\
\hline
\end{tabular}

Source: AMSPP, LE, 409 and 410. 
On other Umbrian farms, maize production was probably even greater, though the available data do not provide a precise overview since they often lack details about cereal quantities and qualities (Bonelli 1967, p. 154). Not even the Gregorian Land Register, compiled in the State of the Church, allows us to go beyond the generic divisions of cultivated plants. By not providing precise indications of the different types of cereals, the information obtained allows us only to speak of "sown" plants (simple or those with trees and vines). This lack of information confirms the companies' habit, already demonstrated during the previous centuries, of taking only generic records about their cereal crops, without adding details about their production (Chiacchella 1996; Biagioli 1975). In Umbria the seeds were intended for about $35 \%$ of the cultivated land but it is completely impossible to know the precise part destined for the production of wheat, maize and other minor cereals (Chiapparino and Moroni 2006). In the absence of more precise findings, the information taken from the accounts of farms, at least the largest and best organized ones, offers the possibility of obtaining an image that better reflects the agricultural reality of the region.

Considering the limits of the sources available, the findings concerning cereal production in the lands belonging to the Marquis Bourbon di Sorbello indicate that the cultivation of maize had a greater relevance there.

Table 2. Wheat and maize production in the Marquis Bourbon di Sorbello's properties, I809-I820 (Staia).

\begin{tabular}{|c|c|c|c|c|}
\hline Years & Wheat & Maize & Total & $\begin{array}{c}\% \text { of maize } \\
\text { in total amount }\end{array}$ \\
\hline 1809 & 1,710 & 1,242 & 2,952 & 42 \\
\hline 1811 & 704 & 1,164 & 1,868 & 62 \\
\hline 1812 & 1,770 & 2,426 & 4,196 & 56 \\
\hline 1816 & 1,924 & 1,406 & 3,330 & 42 \\
\hline 1818 & 2,296 & 2,198 & 4,494 & 49 \\
\hline 1819 & 2,258 & 2,966 & 5,224 & 57 \\
\hline 1820 & 1,676 & 3,346 & 5,022 & 67 \\
\hline Median & 1,762 & 2,107 & 3,869 & 54 \\
\hline
\end{tabular}

Source: ASP, $A B S$, series I, n. 59, Io.

In fact, on the properties of the Marquis Bourbon de Sorbello at the beginning of the nineteenth century, maize averagely represented $54 \%$ of ce- 
reals, with the peaks of production of $62 \%$ and $67 \%$ in 1811 and 1820 respectively. These high rates lasted a long time, since from 1868 to 1879 maize still represented $55 \%$ of the cereal crops on this family's properties. This is an indisputable demonstration of the relevance of the maize crops, though a further investigation is still needed in order to better understand the farming choices of any single landowner. Unfortunately, this research did not consider the production choices of the small owners, with reference to both the owners who lived in a composite rural society as well as those who owned agricultural plots close to their homes. In order to draw a wider picture combining both larger and smaller production strategies, it will be necessary to broaden this research by including data from the accounting books of other local properties, regardless of their dimension. It will be further necessary to analyse not only the general trend, but also the choices made by any single producer, both large and small ones, as well as urban and rural ones, in order to adapt their activities to the commercial policies imposed by the public authorities during the nineteenth century (Pescosolido 2004, 100-102).

In any case, the existing documentation concerning large farms allows us to examine other examples of cereal cultivation practices, such as the case of the beni adiacenti property, a cultivated land owned by the San Pietro monastery in Perugia. As the name reveals (beni adiacenti= adjacent properties), this property consisted of the cultivated lands located just outside the religious building and therefore considered a privileged asset, managed with special care for the introduction of the latest agricultural innovations. On this property, in fact, the production scenario was much more diversified than one could imagine, with a variety of cereal crops which included wheat, maize and durum wheat (grano duro). By comparing the volumes of the Casalina company's production with those of the beni adiacen$t i$, it is possible to observe that in quantitative terms the first company was undoubtedly the larger one, while the second company prevailed in terms of wheat and durum wheat production, two kinds of cereals traditionally employed in the pasta industry. The beni adiacenti company therefore demonstrates a much more varied cereal production, combining different wheats and maize, together with the search for a finer quality in order to satisfy the demand of the nascent pasta factories. Evidence of the presence of these three cereals on the beni adiacenti lands dates back to the early nineteenth century and, though it needs to be confirmed by further research, it suggests that this company had adopted a diversified production strategy that, be- 
tween 1824 and 1860, allowed it to obtain an average production of $610 \mathrm{rub}$ $b i i^{5}$ of wheat, 346 of maize, and 290 of durum wheat per year.

Regardless of the differences among the single study cases, the existence of a cereal crop diversity demonstrates the emergence, from the first decades of the nineteenth century onward, of an agricultural strategy aimed at satisfying different demands, from the consumption of peasant families and monasteries to supplying urban markets and the pasta industry. This production segmentation, which derived from a growing diversification of demand, is confirmed by the price differences among cereals. In the case of the company of the Perugia San Pietro monastery, for instance, at the beginning of the nineteenth century a rubbio of maize was worth 5.1 scudi, a rubbio of wheat $7.7 \mathrm{scudi}$, and a rubbio of durum wheat $8.28 \mathrm{scudi}$, thus demonstrating the existence of different commercial as well as consumer circuits.

From a different point of view, large landowners' accounting books also allow a comparison between the cereal company prices and the cereal urban market prices. Regardless of the difficulties caused by the use of different ancient currencies and units of measurement, it is possible to compare the prices of the examined companies with the series of prices from the Orvieto market for the years from 1824 to 1860 . The result is surprising: the price of a rubbio of maize turns out to be $5.1 \mathrm{scudi}$, the same in both the beni adiacenti company of the Perugia San Pietro monastery and the Orvieto market. We have therefore identified a uniform price which demonstrates once again the existence of widespread market relations that induced a progressive integration of commercial spaces (Herranz Loncan 2016) by overcoming the restrictions of the single local economies (Malanima, 2009). Other clues point in this direction. Between 1825 and 1853, a rubbio of wheat on the lands of the Marquis Bourbon di Sorbello's company was worth 8 scudi, exactly as in the company of the San Pietro monastery and in the Orvieto market. All these data confirm the shaping, during the eighteenth and nineteenth centuries, of an integrated economic area for cereals. Wheat and maize crops, as mentioned above, were progressively integrated and they gave life to a single commercial space.

\section{Conclusions}

The paper confirms the chronology of the spreading of maize on the Italian Peninsula. Using the region of Umbria as a case study, it has been shown 
how maize arrived in the early eighteenth century. In addition to the need for more information on the routes through which maize spread, what is evident is the existence of a time difference between the appearance of maize in urban markets and on farms. The relationship between urban markets and farms must be better studied in order to learn about the economic and agricultural context that allowed the consolidation of maize. The work also highlights how a single cereal market was formed during the 18 th century. The trends of maize and wheat prices are convergent. From this point of view, the research should be deepened, however, the data presented are very clear. The prices of wheat and maize show a total convergence and this applies to a large geographical area where unique prices prevail. This aspect is of great importance to better understand the functioning of preindustrial markets. The existence of a single cereal market is confirmed by the convergence not only of the prices on city markets but also of the similarities between the predominant prices on urban markets and farms. The study shows the need to increase our knowledge of the commercial and production circuits that were formed in Europe during the modern age, following the consolidation of maize on markets and farms.

Bibliography

Archival sources

AB: Archivio Bufalini, San Giustino, Perugia, Italia

AMSPP: Archivio del Monastero di San Pietro, Perugia

\section{LE: Libri Economici}

ASPG: Perugia Archivio di Stato di Perugia

AA: Archivio Antonini, serie 7, numero 5.

ABS: Archivio Bourbon di Sorbello

AUP: Archivio Università di Perugia.

LEU: Archivio Collegio Pio della Sapienza, Libri entrate e uscite

\section{Literature}

Abel, W. 1976. Congiuntura agraria e crisi agrarie. Storia dell'agricoltura e della produzione alimentare nell'Europa centrale dal XIII secolo all'età industriale. Torino: Einaudi.

Alfani, G. 2010. Il Grand Tour dei Cavalieri dell'Apocalisse. L'Italia del "lungo Cinquecento" (1494-1629). Venezia: Marsilio. 
Alfani, G. and Ó Gráda, C. (eds.). 2017. Famine in European History. Cambridge: Cambridge University Press.

Ambrosoli, M. 1992. Scienziati, contadini e proprietari. Botanica e agricoltura nell'Europa occidentale 1350-1850. Torino: Giulio Einaudi editore.

Biagioli, G. 1975. L'agricoltura e la popolazione in Toscana all'inizio dell'Ottocento. Pisa: Pacini.

Biagioli, G. 200o. Il modello del proprietario imprenditore nella Toscana dell'Ottocento: Bettino Ricasoli. Il patrimonio, le fattorie. Firenze: Leo S. Olschki.

Bonelli, F. 1967. Evoluzione demografica ed ambiente economico nelle Marche e nell'Umbria dell'Ottocento. Torino: Industria libraria tipografica editrice.

Caracciolo, A. 1973. 'La storia economica. In Storia d'Italia, III, Dal primo Settecento all'Unità, 511-693. Torino: Einaudi.

Cazzola, F. 2014. Contadini e agricoltura in Europa nella prima età moderna. Bologna: Clueb.

Chiacchella, R. 1996. Ricchezza, nobiltà e potere in una provincia pontificia. La "misura generale del territorio perugino" del 1727. Napoli: Edizioni Scientifiche Italiane.

Chiapparino, F. and M. Moroni. 2006. 'Paesaggio agrario e assetti colturali nelle Marche e nell'Umbria tra Otto e Novecento.' In Per un atlante dell'agricoltura italiana. Il seminativo nel primo Ottocento, edited by S. Russo, 17-19. Bari: Edipuglia.

Coppola, G. 1979. Il mais nell'economia agricola lombarda (dal secolo XVII all'Unità). Bologna: il Mulino.

Cova, A. 1992. 'L'economia lombarda tra tradizione e innovazione: l'agricoltura.' In Veneto e Lombardia tra rivoluzione giacobina ed età napoleonica. Economia, territorio, istituzioni, edited by G. L. Fontana and A. Lazzarini, 25-44. Milano-Bari: Cariplo-Laterza.

Cuocco, V. 2008. 'Viaggio in Molise'. In Scrittori italiani di viaggio. First Volume, 1700-1861, edited by L. Clerici, 399-426. Milano: Arnoldo Mondadori.

De Bernardi, A. 1984. 'Pellagra, Stato e scienza medica: la curabilità impossibile.' In Storia d'Italia. Annali 7. Malattia e medicina, edited by F. Della Peruta, 681-704. Torino: Einaudi.

De Maddalena, A. 1974. Prezzi e mercedi a Milano dal 1701 al 186o. Milano: Banca Commerciale.

Desplanques, H. 1969. Compagnes ombriennes: contribution a l'etude des paysages ruraux en Italie centrale. Paris: A. Colin. 
Doria, A. 2002. 'Le colture del nuovo mondo.' In Storia dell'agricoltura italiana, II, Il Medioevo e l'Età moderna, edited by G. Pinto, 569-578. Firenze: Edizioni Polistampa.

Epstein, S. R. 200o. Freedom and growth. The rise of states and markets in Europe, 1300-1750. London-New York: Routldge.

Federico, G. 2007. 'Market Integration and Market Efficiency. The Case of 19th Century Italy.' Explorations in Economic History, 44 (2): 293-316.

Finzi, R. 2009. «Sazia assai ma dà poco fiato». Il mais nell'economia e nella vita rurale italiana. Bologna: Clueb.

Finzi, R. 1982. 'Quando e perché fu sconfitta la pellagra.'I In Salute e classi lavoratrici in Italia dall'Unità al fascismo, edited by M. L. Berti, 391-429. FrancoAngeli: Milano.

Franconie, H. 1997, 'Mais et millet dans les dialectes européens.' Journal d'agriculture traditionelle et de botanique appliquée, 1: 149-178.

Galli, M. 2016. La conquête alimentaire du Nouveau Mondo. Pratiques et représentations franco-italiennes des nouveaux produits du XVI ${ }^{e}$ au XVIII siècle. Paris: L'Harmattan.

Gentilcore, D. 2017. 'The Impact of New World Plants, 1500-1800: The Americas in Italy.'I In The New World in Early Modern Italy 1492-1750, edited by E. Horodowich, 190-205. Cambridge: Cambridge University Press.

Gori, O. 1989. 'Mercato e prezzi del grano a Firenze nel secolo XVIII.' Archivio storico italiano, 147 (3): 525-623.

Heine, P. 2017. Delizie d'Oriente. Una storia della cultura gastronomica. Palermo: Sellerio.

Herranz Loncan, A. 2016. 'Una aproximación a la integración de los mercados españoles durante el siglo XIX.'I In Estudios sobre el desarrollo económico español. Dedicados al Profesor Eloy Fernández Clemente, edited by D. Gallego Martínez, 313-333. Zaragoza: Prensas Universitarias de Zaragoza.

Labrousse, E. 1932. Esquisse du mouvement des prix et des revenusen France au XVIIIe siècle. Paris: Dalloz.

Levi, G. 1991. 'L'energia disponibile.' In Storia dell'economia italiana, II, L'età moderna: verso la crisi, 141-168. Torino: Einaudi.

Livi Bacci, M. 1987. Popolazione e alimentazione. Saggio sulla storia demografica europea. Bologna: il Mulino.

Malanima, P. 1976. 'Aspetti di mercato e prezzi del grano e della segale a Pisa dal 1548 al 1818.'I In Ricerche di storia moderna, I, edited by M. Mirri, 289328. Pisa: Pacini. 
Malanima, P. 2009. 'Progresso o stabilità? Il mercato nelle economie preindustriali.' Studi storici, 50 (3): 634-651.

Malanima, P. 2016. 'Cibo e povertà nell'Italia del Sette e Ottocento.' Rivista di storia economica e sociale, 1: 1-25.

Malanima, P. (n.d.), Wheat prices in Tuscany, 1260-1860, http://www.paolomalanima.it/default_file/Italian\%2oEconomy/Wheat_Prices_Tuscany.pdf.

Mantelli, R. 1998. 'L'epoca della diffusione del mais. La maiscoltura nell'evoluzione economica dell'Italia (fine XVI secolo - fine XIX secolo).'I In Prodotti e tecniche d'oltremare nelle economie europee. Secc. XIII-XVIII, edited by S. Cavaciocchi, 451-465. Firenze: Le Monnier.

Messedaglia, L. 1927. Il mais e la vita rurale italiana. Saggio di storia agraria. Piacenza: Federazione italiana dei consorzi agrari.

Mineccia, F. 1983. 'Note sulle fattorie granducali del pisano occidentale nell'età moderna: Antignano, Casabianca, Collesalvetti, Nugola, S. Regolo e Vecchiano.'I In Agricoltura e aziende agrarie nell'Italia centro-settentrionale (secoli XVI-XIX), edited by G. Coppola, 285-341. Milano: Franco Angeli.

Mocarelli, L. 2015. 'Ripensare le crisi alimentari: lo Stato di Milano nel secondo Settecento'. in «Moia la carestia». La scarsità alimentare in età preindustriale, edited by M. Vaquero Piñeiro, 39-63. Bologna: il Mulino.

Mocarelli L. and M. Vaquero Piñeiro. 2018. 'El maíz en Italia, siglos XVI-XIX: precios, mercados y haciendas agrícolas (dos casos de estudio: Lombardía y Umbría).' In Obradoiro de historia moderna 27: 21-48.

Moroni, M. 2016. 'Organizzazione aziendale, indirizzi produttivi e rapporti con il mercato nelle terre della Santa Casa di Loreto.' In Marca/Marche. Rivista di storia regionale7: 87-114.

Nenci, G. 1989. 'Proprietari e contadini nell'Umbria mezzadrile.' In Storia d'Italia. Le regioni dall'Unità a oggi. L'Umbria, edited by R. Covino, 189257. Torino: Einaudi.

Parenti, G. 1942. Prezzi e mercato del grano a Siena (1546-1765). Firenze: Casa editrice del dott. Carlo Cya.

Persson, K. G. 1999. Grain markets in Europe. Integration and deregulation, 1500-1900. Cambridge: Cambridge University Press.

Pescosolido, G. 2004. Agricoltura e industria nell'Italia unita. Roma-Bari: Laterza.

Pescosolido, G. 2007. Unità nazionale e sviluppo economico in Italia 1750-1913. Roma-Bari: Laterza. 
Plantes et cultures 1992. Plantes et cultures nouvelles en Europe occidentale au Moyen Age et à l'époque modern. Flaran: Centre culturel de l'Abbaye de Flaran.

Poni, C. (ed.) 1978. 'Azienda agraria e microstoria.' Quaderni storici 13 (3): 1-39.

Rebourg, C. et al. 2003. 'Maize introduction in Europe: the history reviewed in the light of molecular data', in Theoretical and applied genetics 106 (5): 895-903.

Romano, R. (ed.). 1967. I prezzi in Europa dal XIII secolo a oggi. Torino: Einaudi.

Sereni, E. 1997. Storia del paesaggio agrario italiano. Roma-Bari: Laterza.

Visceglia, A.M. 1991. 'I consumi in Italia in età moderna, I' In Storia dell'economia italiana, II, L'età moderna: verso la crisi, 226-229. Torino: Einaudi.

Vaquero Piñeiro, M. and F. Giommi. 2017. L'Umbria nelle "memorie" inedite dell'Inchiesta agraria Jacini (1877-1884). Perugia: Editoriale Umbra Istituto per la Storia dell'Umbria Contemporanea.

Vivanti, C. 1967. 'I prezzi di alcuni prodotti agricoli a Mantova nella seconda metà del XVIII secolo.' In I prezzi in Europa dal XIII secolo a oggi, edited by R. Romano, 421-436. Torino, Einaudi. 